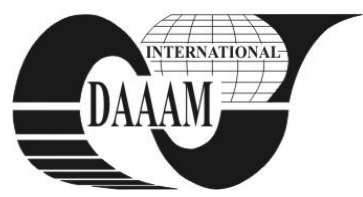

Annals of DAAAM for 2011 \& Proceedings of the 22nd International DAAAM Symposium, Volume 22, No. 1, ISSN 1726-9679 ISBN 978-3-901509-83-4, Editor B. Katalinic, Published by DAAAM International, Vienna, Austria, EU, 2011 Make Harmony between Technology and Nature, and Your Mind will Fly Free as a Bird Annals \& Proceedings of DAAAM International 2011

\title{
CORROSION RESISTANCE OF ALUMINIUM ALLOY IN THE AQUEOUS SOLUTION OF UREA
}

\author{
NEMCOVA, A[neta]; NOVOTNA, E[va]; PACAL, B[ohumil] \& TULKA, J[aromir]
}

\begin{abstract}
This paper deals with corrosion behaviour of the AlCu4Mg1 wrought aluminium alloy with $99.5 \%$ Al coating on the surface. Corrosion tests were performed as a modified OECD technique in two different kind of corrosion environment (aqueous solution inclusive $0.1 \mathrm{~mol}$ of urea and solution inclusive $0.1 \mathrm{~mol}$ of $\mathrm{NaCl}$ dissolved in the water). The main goal of this work was assessed the influence of urea at aluminium alloy in the aqueous solutions.
\end{abstract}

Key words: corrosion process, aluminium, urea, OECD

\section{INTRODUCTION}

Frequent uses of aluminium alloys are in the automotive and aerospace industry. However, untreated aluminium alloys based on $\mathrm{Al}-\mathrm{Mg}-\mathrm{Cu}$ are susceptible to corrosion in aggressive atmospheres (Fontana, 1978; Ghali, 2010).

The resistance of $\mathrm{Al}$ against corrosion in aqueous media can be attributed to a rapidly formed surface oxide film, which is composed mainly of $\mathrm{Al}_{2} \mathrm{O}_{3}, \mathrm{Al}(\mathrm{OH})_{3}$ and $\mathrm{AlO}(\mathrm{OH})$ phases. Nevertheless, the presence of aggressive ions like chlorides causes significant attack (Mishra \& Balasubramaniam, 2007). The main corrosion process that is developed on the surface of $\mathrm{Al}$ alloys in a $\mathrm{NaCl}$ solution is the localized alkaline corrosion in the $\mathrm{Al}$ matrix surrounding $\mathrm{Al}(\mathrm{Mn}, \mathrm{Fe}, \mathrm{Cr})$ cathodic intermetallics (Szklarska-Smialowska, 1999).

\section{EXPERIMENTAL MATERIAL}

As experimental material the $\mathrm{AlCu} 4 \mathrm{Mg} 1$ wrought aluminium alloy with $99.5 \% \mathrm{Al}$ coating was used. The material was received as a sheet with dimensions $30 \times 50 \times 1 \mathrm{~mm}$. The chemical composition of pure $\mathrm{Al}$ on the surface and substrate under this coating was measured by glow discharge optical emission spectroscopy (GDOES) using Spectrumat GDS-750 device (see Tab. 1).

\section{EXPERIMENTAL PROCEDURE}

Corrosion tests were performed as a modified OECD technique. The samples were placed into the small testing cells for provision no interaction of the samples. There were $30 \mathrm{ml}$ of corrosion solution on the bottom of each cell and the samples were hung up above the surface. Testing mode was cyclical $\left(8 \mathrm{hrs} 35^{\circ} \mathrm{C}, 16 \mathrm{hrs} 23^{\circ} \mathrm{C}-1\right.$ cycle $)$. The experiments were carried out with increasing exposition time $(1,5,10,20,31$ and 42 cycles).

Two different kind of corrosion environment were tested. One of them was the aqueous solution inclusive $0.1 \mathrm{~mol}$ of urea and the second type was solution inclusive $0.1 \mathrm{~mol}$ of $\mathrm{NaCl}$ dissolved in the water.

Final cleaning of the specimens after exposition was carried out by dipping in a solution of $\mathrm{CrO}_{3}+\mathrm{H}_{3} \mathrm{PO}_{4}+\mathrm{H}_{2} \mathrm{O}$; according to Czech standard (ČSN ISO 8407, 1995). The weight loss was measured at analytical balances $(d=0.1 \mathrm{mg})$ after each experiment.

\begin{tabular}{|c|c|c|c|c|c|c|c|}
\hline & $\mathrm{Si}$ & $\mathrm{Fe}$ & $\mathrm{Cu}$ & $\mathrm{Mn}$ & $\mathrm{Mg}$ & $\mathrm{Zn}$ & $\mathrm{Ti}$ \\
\hline Surface & 0.12 & 0.20 & 0.01 & 0.00 & 0.01 & 0.02 & 0.02 \\
\hline Substrate & 0.19 & 0.21 & 4.40 & 0.44 & 1.69 & 0.03 & 0.04 \\
\hline
\end{tabular}

Tab. 1.The chemical composition of pure $\mathrm{Al}$ on the surface and the main alloying elements of $\mathrm{AlCu} 4 \mathrm{Mg} 1$ alloy in substrate

\section{RESULTS}

After experimental cycles the weight losses were evaluated and the statistic analysis was performed. First the Dixon test of extreme deviations with evaluation of maximal and minimal values was performed. Subsequently, the weight losses $\left[\mathrm{mg} . \mathrm{dm}^{-2}\right]$ and corrosion rate $\left[\mathrm{g} \cdot \mathrm{m}^{-2} \mathrm{~d}^{-1}\right]$ were calculated from the measured values. This data were fitted with optimal functions.

The weight losses of experimental material for system of aqueous solution inclusive $0.1 \mathrm{~mol}$ of urea as a function of time exposure are presented in Fig. 1a). The best fit for relationship of weight losses - time corresponds to function A. $\mathrm{x}^{\wedge} \mathrm{B}$, where $\mathrm{A}=0.319 ; \mathrm{B}=0.391$; correlation coefficient $\mathrm{R}=0.708$.

Fig. 1b) shows the dependence of corrosion rate on time of exposure in accordance with function $A \cdot x^{\wedge} B$, where $\mathrm{A}=0.031, \mathrm{~B}=-0.528$; correlation coefficient $\mathrm{R}=-0.788$.

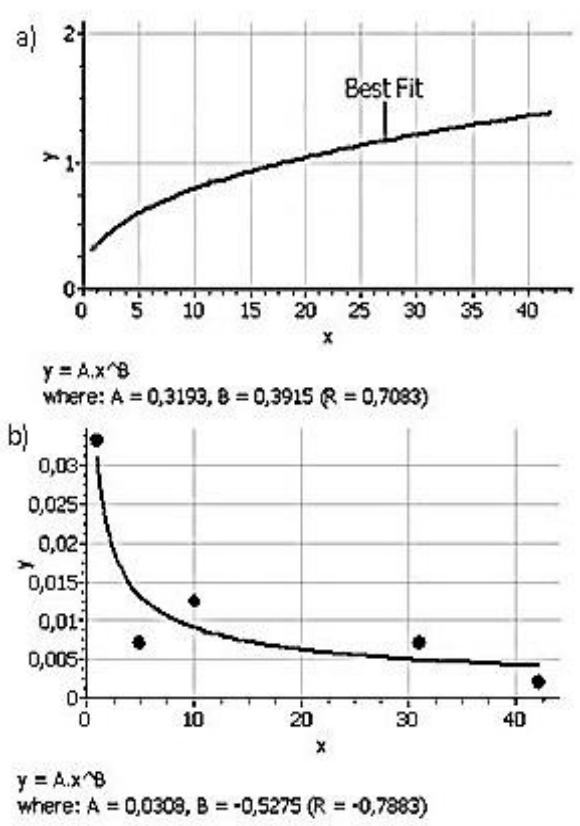

Fig. 1.The time dependence a) of weight losses of experimental material in the aqueous solution of urea ( $\mathrm{x}$ - time in days, $\mathrm{y}-$ weight losses in mg.dm ${ }^{-2}$ ); b) of corrosion rate of experimental material in the aqueous solution of urea ( $\mathrm{x}$ - time in days, $\mathrm{y}-$ corrosion rate in $\mathrm{g} \cdot \mathrm{m}^{-2} \mathrm{~d}^{-1}$ ) 


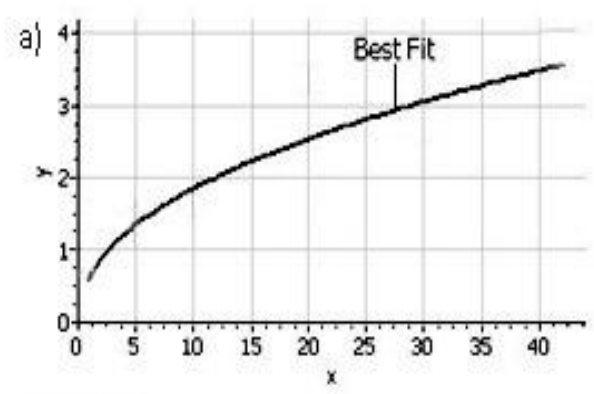

$y=A, x^{\wedge} B$

where: $A=0,6537, B=0,4533(R=0,9572)$

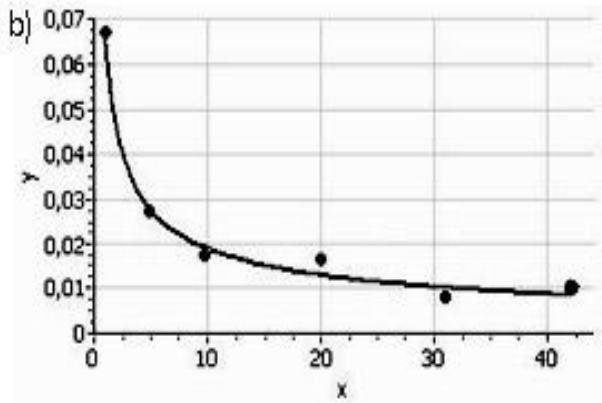

$y=A \cdot x^{\wedge} B$

where: $A=0,0652, B=-0,5335(R=-0,9712)$

Fig. 2.The time relationship in the aqueous solution of $\mathrm{NaCl}$ a) of weight losses ( $\mathrm{x}$ - time in days, $\mathrm{y}$-weight losses in $\mathrm{mg} . \mathrm{dm}^{-}$ $\left.{ }^{2}\right)$; b) of corrosion rate ( $\mathrm{x}-$ time in days, $\mathrm{y}-$ corrosion rate in $\mathrm{g} \cdot \mathrm{m}^{-2} \mathrm{~d}^{-1}$ )

The relationship between time of exposure and weight losses of experimental material for system of aqueous solution inclusive $0.1 \mathrm{~mol}$ of $\mathrm{NaCl}$ is presented in Fig. 2a). The best fit for measured data of weight losses versus time of exposure are corresponding to the function $\mathrm{A} \cdot \mathrm{x}^{\wedge} \mathrm{B}$, where $\mathrm{A}=0.654$; $\mathrm{B}=0.453$; correlation coefficient $\mathrm{R}=0.957$.

The dependence of corrosion rate on time of exposure in accordance with function $\mathrm{A} \cdot \mathrm{x}^{\wedge} \mathrm{B}$, where $\mathrm{A}=0.065, \mathrm{~B}=-0.534$; correlation coefficient $R=-0.971$ is shown in Fig. $2 b$ ).

\section{DISCUSION}

The results of corrosion weight losses and corrosion rate for aluminium sheet $(\mathrm{AlCu} 4 \mathrm{Mg} 1$ with pure $\mathrm{Al}$ on the surface) in two different corrosion environment (aqueous solution inclusive $0.1 \mathrm{~mol}$ of urea and solution inclusive $0.1 \mathrm{~mol}$ of $\mathrm{NaCl}$ dissolved in the water) are presented in this work.

The experimental technique was chosen in accordance with known experience that any particular relationship between resistance against salt fog and resistance against corrosion in other environments don't exist. Therefore, the results of corrosion test don't consider direct information about corrosion resistance in the particular environment. Consequently, the main goal of this work wasn't testing of corrosion resistance in different environment but the influence of urea was assessed. As well, the effect of crypto-climatic conditions was ascertained.

\begin{tabular}{|c|c|c|}
\hline Environment & {$\left[\mathrm{g} \cdot \mathrm{m}^{-2} \mathrm{~d}^{-1}\right]$} & {$[\mu \mathrm{m} / \mathrm{y}]$} \\
\hline Water + 0.1 mol of urea & 0.033 & 3.26 \\
\hline Water $+0.1 \mathrm{~mol}$ of $\mathrm{NaCl}$ & 0.067 & 6.61 \\
\hline
\end{tabular}

Tab. 2.The corrosion rate after 1 day exposition and calculation of corrosion rate in $\mu \mathrm{m}$ per year
The results for aqueous solution of $\mathrm{NaCl}$ can be considered as expected. Therefore, the attention was focused on the issue of occurrence of the urea.

Three cases were considered:

- the urea will be distinguished on inhibitive effect, which is known for ferrous metal in aqueous solution,

- the urea will additive even synergically stimulate corrosion process of aluminium alloys in solutions inclusive chloride ions at elevated temperatures,

- the urea won't significantly affected the character of corrosion process of aluminium alloy.

In first approach, it was estimate that the influence of urea wasn't in this system the most significant. The results show that kinetics of corrosion process in the initial period was crucial and during longer times of exposure was observed relative stabilization of corrosion rate. It can be assume that the passivation of the surface of aluminium alloys was significantly applied and partially disrupted by stimulative effect of chloride ions.

Calculated values for initial period are presented in Tab. 2 . The values after first days of exposition ware considered like the most dangerous. For initial period the confidence interval at $90 \%$ probability was determined: $4.65 \mu \mathrm{m} / \mathrm{y} \leq$ corrosion rate $\leq 11.79 \mu \mathrm{m} / \mathrm{y}$.

\section{CONCLUSIONS}

The cyclic corrosion tests were performed for laboratory testing of aluminium alloy. The results of this work confirm already known data about low corrosion resistance of aluminium alloys in aqueous solution with chloride ions. Nevertheless, the verification of the urea effect can be considered as contributing for other research (i.e. corrosion test of $\mathrm{AlCu} 4 \mathrm{Mg} 1$ in the aqueous solution inclusive $0.07 \mathrm{~mol}$ of urea $+0.03 \mathrm{~mol}$ of $\mathrm{NaCl}$ ).

The significant technical differences of corrosion process weren't observed in system aluminium alloy/aqueous solution of urea. The inhibitive effect of urea (known for ferrous metal in the aqueous solution) hasn't been confirmed. Even, any stimulative effect of urea on corrosion process of aluminium alloys wasn't found out. For initial period the $90 \%$ probability that tested systems can be considered identical with expected non-uniform type of corrosion $10 \mu \mathrm{m} / \mathrm{y}$ exists.

\section{ACKNOWLEDGEMENTS}

This research was supported by project of Ministry of Industry and Trade of the Czech Republic no. FR TI 1/274 and by Slovak-Czech women's fund.

\section{REFERENCES}

ČSN ISO 8407. (1995). Koroze kovů a slitin. Odstraňováni koroznich zplodin ze vzorků podrobených koroznim zkouškám, Český normalizační institut, Czech republic, (in czech)

Fontana, M.G. (1978). Corrosion engineering. McGraw-Hill, USA

Ghali, E. (2010). Corrosion resistence of Aluminium and Magnesium Alloy, Wiley, ISBN 978-0-471-71576-4, USA

Mishra, A.K. \& Balasubramaniam, R. (2007). Corrosion inhibition of aluminium by rare earth chlorides. Materials Chemistry and Physics. Vol. 103 (June 2007) 385-393, ISSN 0254-0584

Szklarska-Smialowska, Z. (1999). Pitting corrosion of aluminum. Corrosion Science. Vol. 41 (August 1999) 1743-1767, ISSN 0010-938X 